dr Małgorzata Pagacz USJK ${ }^{1}$

ORCID: 0000-0003-4504-9142; mmpagacz@gmail.com

Akademia Katolicka w Warszawie

\title{
Tajemnica Serca Jezusa Konającego źródłem apostolstwa według św. Urszuli Ledóchowskiej
}

\section{Streszczenie}

Artykuł przedstawia tajemnicę Serca Jezusa Konającego jako źródło apostolstwa według św. Urszuli Ledóchowskiej. Tajemnica ta znajduje się w centrum duchowości św. Urszuli i założonego przez nią zgromadzenia. Miłość Boża objawiła się najpełniej w Sercu Jezusa Konającego. Skierowane z krzyża wezwanie Zbawiciela: „Pragnę” jest wołaniem o miłość. Zdaniem Matki Ledóchowskiej odpowiedzią na skargę Jezusa jest konkretna postawa apostolska - podejmowany wysiłek, by wszyscy ludzie poznali i umiłowali Chrystusa.

Słowa kluczowe: Serce Jezusa Konającego, apostolstwo, krzyż, Urszula Ledóchowska, duchowość

\section{Abstract}

The Mystery of the Agonizing Heart of Jesus as the Source of Apostolate according to Saint Ursula Ledóchowska

The article presents the mystery of the Agonizing Heart of Jesus as a source of apostolate, according to Saint Ursula Ledóchowska. This mystery is in the centre of the spirituality of Saint Ursula and the congregation she founded. God's love was manifested to the fullest in the Agonizing Heart of Jesus. The request, that comes from the Cross of the Redeemer: "I thirst" is a cry for love. According to Mother Ledóchowska, the reply to this call is a specific apostolic attitude - the effort undertaken, so that all the people can recognize and love Christ.

1 Małgorzata Pagacz USJK - doktor nauk teologicznych, należy do Zgromadzenia Sióstr Urszulanek Serca Jezusa Konającego, teolog duchowości, mgr matematyki (Uniwersytet Jagielloński), wykładowca, odpowiedzialna za formację profesek czasowych swego Zgromadzenia. 
Keywords: Agonizing Heart of Jesus, apostolate, Cross, Ursula Ledóchowska, spirituality

Tajemnica Serca Jezusa Konającego znajduje się w centrum duchowości św. Urszuli Ledóchowskiej (1865-1939). W swoich pismach Święta pozostawiła wiele tekstów, rozważań i modlitw skupiających się wokół tej tajemnicy, świadczących zarazem o głębi jej życia duchowego. Odkrywanie i kontemplacja miłości Serca Jezusa Konającego oraz wprowadzanie w czyn owoców tej modlitwy stanowi treść całego ziemskiego życia Matki Ledóchowskiej. Przyjmuje ona tę tajemnicę - i to, co z niej wynika - jako osobisty program życia i działania.

Tajemnica Serca Jezusa Konającego jest kluczowa dla zgromadzenia zakonnego, założonego przez Matkę Ledóchowską. Apostolska wspólnota, która powstała za pośrednictwem św. Urszuli w 1920 roku, z woli Kościoła otrzymała predykat: od Serca Jezusa Konającego ${ }^{2}$. Tajemnica ta została zatem powierzona siostrom jako źródło duchowości i misji. Teksty św. Urszuli, dotyczące rozważanej tajemnicy, znajdują się przede wszystkim w pismach skierowanych do jej duchowych córek. Najważniejsze z nich to: Pisma zakonne (składające się z Testamentu, Dyrektorium i Rekolekcji miesięcznych) oraz Rozmyślania, które zostały przygotowane jako rozważania do poszczególnych fragmentów Ewangelii, konkretne wskazania i zachęty, pomocne do osobistej modlitwy sióstr.

Niniejszy artykuł ma na celu ukazanie i uzasadnienie, dlaczego i w jaki sposób tajemnica Serca Jezusa Konającego jest źródłem apostolstwa według św. Urszuli Ledóchowskiej. Kwestia ta nie została dotychczas podjęta w żadnej publikacji. Na początku zostanie więc przedstawione zagadnienie tajemnicy Serca Jezusa Konającego w pismach Matki Ledóchowskiej. Zostało ono już w pewnej mierze opracowane przez Jerzego Misiurka ${ }^{3}$, jednak warto poświęcić mu więcej uwagi, analizując i omawiając teksty św. Urszuli, które nie są uwzględnione w wymienionym

2 Zob. Konstytucje Zgromadzenia Sióstr Urszulanek Serca Jezusa Konającego, Warszawa 2016, s. 8.

3 Zob. J. Misiurek, Kontemplacja Serca Jezusa Konającego i duchowość eucharystyczna, w: Polka w Europie. Święta Urszula Ledóchowska, Lublin 2005, s. 28-42. 
artykule. Ponadto w duchowości Matki Ledóchowskiej tajemnica Serca Jezusa Konającego jest zagadnieniem fundamentalnym, które można ujmować wieloaspektowo. W drugim punkcie niniejszego artykułu będzie mowa o kontemplacji wyznania Jezusa „Pragnę”, tak jak je rozumie św Urszula. Natomiast ostatni trzeci punkt ukaże apostolstwo właśnie jako odpowiedź na pragnienia i miłość Zbawiciela.

\section{Tajemnica Serca Jezusa Konającego}

Matka Ledóchowska w swoich pismach wielokrotnie zatrzymuje się nad prawdą o miłości Boga, najpełniej wyrażonej przez krzyż Chrystusa, którą zarazem ukazuje przebite Serce Zbawiciela. Jedną z osiemnastu próśb, które składają się na jej Testament, przeznacza na ukazanie miłości ukrzyżowanego Chrystusa. Według św. Urszuli nabożeństwo do Jezusa ukrzyżowanego, szczególnie dla osoby zakonnej, jest „duszą całego jej życia wewnętrznego, duszą życia jej duszy”" . W Testamencie, który można uznać za podstawę i syntezę duchowości św. Urszuli ${ }^{5}$, pisze ona:

Na krzyżu [Chrystus] dał sobie przebić Serce, by Ono stało się dla nas ucieczką i ochroną, i rajem duszy, by Ono zawsze dla nas było otwartym źródłem łask i miłości. [...] Wszystko, co dobre, wzniosłe, święte w dziedzinie życia nadprzyrodzonego, z krzyża na świat spłynęło, bo to wszystko Chrystus na krzyżu męką i śmiercią swą nam wysłużył. I dlatego do krzyża dusze zakonne powinny kierować oczy swe jak kwiat do słońca. W krzyżu zbawienie, w krzyżu nadzieja nasza, w krzyżu miłość, i szczęście, i wszystko nasze, bo na krzyżu Jezus Krwią swą Przenajświętszą nas odkupił, drzwi nieba dla nas otworzył, męką swą nam wieczną radość zapewnit ${ }^{6}$.

Powyższe słowa ukazują niezgłębione znaczenie ofiary krzyżowej Zbawiciela. Chrystus oddający swoje życie z miłości do Ojca i do każdego człowieka stoi w centrum życia św. Urszuli. Ten przewodni rys jej duchowości jednoznacznie wyraża jej predykat: „od Jezusa Ukrzyżowanego”.

4 U. Ledóchowska, Pisma zakonne, Pniewy 2000, s. 35.

5 Zob. W. Misztal, „Testament” św. Urszuli jako synteza duchowości. Lektura tylko dla urszulanek Serca Jezusa Konającego?, w: Św. Urszula Ledóchowska: kobieta w Kościele i społeczeństwie, red. M. Krupecka, W. Misztal, Kraków 2015, s. 74-78.

6 U. Ledóchowska, Pisma zakonne, dz. cyt., s. 35-36. 
Tajemnicą, która jest również bardzo bliska Matce Ledóchowskiej, jest tajemnica Serca Jezusa, które ukazuje niepojętą miłość Boga. Serce Zbawiciela oznacza zarazem osobę Wcielonego Syna Bożego, który nieskończenie miłuje człowieka. Jak zauważa Wojciech Zyzak, z czasem w duchowości Matki Urszuli kontemplacja Chrystusa Ukrzyżowanego koncentruje się na Sercu Jezusa Konającego ${ }^{7}$.

Święta Urszula zwraca uwagę swoim duchowym córkom, że nabożeństwo do Najświętszego Serca Jezusa Konającego jest szczególnie zadane właśnie siostrom ich zgromadzenia zakonnego. Łączy się ono bezpośrednio z tajemnicą Jezusa Ukrzyżowanego, ponieważ na krzyżu Jego Serce zostało przebite i otwarte dla każdego. „Na tym krzyżu poznajemy, co Jezus dla nas wycierpiał, jakie męki, jakie konanie, aby nam dać Serce swoje jako drogocenny, największy skarb w życiu doczesnym - naszą pociechę, naszą radość, naszą miłość" - zauważa Matka Ledóchowska. Ważne świadectwa umiłowania przez św. Urszulę Serca Chrystusa cierpiącego, który z miłości pozwala, by odebrano Mu życie, zapisane są w jej Rozmyślaniach. Wiele medytacji znajdujących się $\mathrm{w}$ tym dziele skupia się wokół Serca Jezusa zranionego grzechami człowieka. Rozmyślania zawierają liczne przykłady kontemplacji tajemnicy miłości Zbawiciela, wyrażonej w Jego Sercu. Matka Ledóchowska pisze:

„O Serce Jezusa Konającego, dziś klęcząc w myśli u stóp krzyża, chcę wznieść wzrok mój ku Tobie. Serce Twe kona z miłości i bólu. Z bólu, bo wziąłeś na siebie pokutę za grzechy całego świata. Z miłości, bo nas, bo mnie tak gorąco ukochałeś, żeś życie swe oddał za mnie, za mnie grzeszną, nędzną" ". Święta Urszula, dotknięta i poruszona miłością Zbawiciela, zadaje Jezusowi pytanie: „Cóż ja dać mogę Tobie?”10.

Tym samym chce ona z wdzięcznością odpowiedzieć Chrystusowi na Jego ofiarne oddanie. Dostrzega wyraźnie, że Zbawiciel w sposób

7 Zob. W. Zyzak, Kontemplacja Krzyża jako centrum duchowości św. Urszuli Ledóchowskiej, w: „Otrzymała od Boga wielki charyzmat”. Św. Urszula Ledóchowska i Urszulanki Serca Jezusa Konającego, red. M. Krupecka, W. Misztal, Kraków 2012, s. 93.

8 U. Ledóchowska, Pisma zakonne, dz. cyt., s. 107-108.

9 U. Ledóchowska, Rozmyślania dla Sióstr Urszulanek Serca Jezusa Konającego, t. 2, Pniewy 2000, s. 39-40.

10 U. Ledóchowska, Rozmyślania dla Sióstr Urszulanek Serca Jezusa Konającego, dz. cyt., s. $39-40$. 
wolny bezgranicznie poświęca się dla zbawienia człowieka, gdyż Jego Serce napełnione jest najczystszą miłością i dobrocią. Chrystus pragnie obdarzyć każdego pełnią życia i radości. Autorka Rozmyślań, zwracając się do Jezusa w słowach modlitwy, wyznaje: „Chcesz mi dać szczęście swoje, bo chcesz małe, nędzne moje serce przykuć do swego Serca i chcesz, bym zawsze była przy Tobie"11. Matka Ledóchowska ma świadomość, że człowiek tylko wtedy znajdzie spokój i szczęście w życiu doczesnym i wiecznym, jeśli będzie ściśle złączony z Sercem Odkupiciela. Zapisywane przez św. Urszulę słowa rozważań i modlitw stanowią świadectwo odkrywania niepojętej miłości Zbawiciela i Jego niezmierzonej dobroci, która sprawiła, że Chrystus nie cofnął się przed ofiarą i cierpieniem, gdyż pragnie wszystkich doprowadzić do zbawienia.

Matka Ledóchowska wpatruje się w Serce Jezusa, które zostało przebite włócznią. Wskazuje, że dzięki tej ranie, jest Ono już zawsze otwarte dla wszystkich, a zwłaszcza dla zagubionych i grzesznych. „Serce to staje się bezpiecznym schronieniem dla serc szukajaccych Boga i zbawienia. Świat ciągnie biedną duszę do siebie, pokusy ją nagabują, czuje się otoczona niebezpieczeństwami. Gdzie się schroni przed nieprzyjacielem, który wszędzie na nią czyha?"12 - pyta autorka Rozmyślań. I zapewnia:

Oto Serce Jezusa jest dla niej otwarte, więc już skarżyć się nie może, że jest bezdomna. Wróbel ma swe gniazdko, gołębica swą jamę skalną, a ona - Boskie Serce Jezusa, do którego może zawsze się uciekać, chronić, przebywać w Nim w cichości, daleko od świata, tak jak dziecko na łonie matki (zob. Ps 131, 2) ${ }^{13}$.

Święta Urszula pokazuje, że pełne miłości Serce Jezusa Konającego jest gotowe być mieszkaniem dla każdego, kto chce się w Nim znaleźć. W tym kontekście Matka Ledóchowska poleca siostrom pytać się siebie, czy naprawdę uciekają się do tego schronienia, czy starają się przez skupienie i milczenie trwać z ufnością i spokojem w Boskim Sercu. „Jezus

\footnotetext{
s. $39-40$.

12 U. Ledóchowska, Rozmyślania dla Sióstr Urszulanek Serca Jezusa Konającego, dz. cyt., s. 79-80.

13 U. Ledóchowska, Rozmyślania dla Sióstr Urszulanek Serca Jezusa Konającego, dz. cyt., s. 80.
}

U. Ledóchowska, Rozmyślania dla Sióstr Urszulanek Serca Jezusa Konającego, dz. cyt., 
ma o mnie staranie, ale On mną tym bardziej się zaopiekuje, im bardziej ja Nim będę zajęta"14 - zapewnia św. Urszula.

Serce Jezusa Konającego jest zranione ludzkimi grzechami i wyniszczone. Wpatrywanie się w przebite włócznią Serce Zbawiciela nie powoduje jednak przerażenia ani lęku. Matka Ledóchowska zwraca uwagę, że rana tego Serca nie jest oskarżeniem ani wyrzutem dla człowieka, lecz zdaje się mówić:

Oto przebłaganie za grzechy twoje! Nie upadaj na duchu, choćby grzechy twoje były czerwone jak szkarłat, we krwi Serca mego staną się białe jak śnieg (zob. Iz 1, 18), tylko ufaj i uciekaj się do mnie o przebaczenie! $!^{15}$

Ta świadomość rodzi wdzięczność wobec Zbawiciela - Jego zranione Serce sprawia, że grzesznik może powiedzieć Ojcu Przedwiecznemu: Ojcze, zgrzeszyłem, ale daruj, oto Serce Twego Syna przebłaga Cię za moje grzechy ${ }^{16}$. Święta Urszula pokazuje, że prawdziwa wdzięczność Chrystusowi za Jego ofiarną miłość wyraża się w szczerym żalu za grzechy i w ufności pokładanej w Jego miłosierdziu.

Autorka Rozmyślań, kontemplując Serce Jezusa Konającego, dostrzega w Nim wzór najgłębszej pokory. Boskie Serce Zbawiciela oddającego swe życia na Kalwarii jest godne wszelkiej chwały - Ono wstępuje do największych przepaści pokory i przyjmuje poniżenia, wzgardę, zelżywości ${ }^{17}$. Jest ofiarą za grzechy wszystkich ludzi. Matka Ledóchowska zauważa: „Ono konało z bólu, włócznią przebite, i z tego Serca wypłynęły ostatnie krople krwi jako ofiara przebłagalna za moje grzechy, ofiara strawiona ogniem świętej miłości na ołtarzu krzyża"18. Kontemplacja miłości Zbawiciela prowadzi św. Urszulę do osobistej decyzji całkowitego oddania się

14 U. Ledóchowska, Rozmyślania dla Sióstr Urszulanek Serca Jezusa Konającego, dz. cyt., s. 80.

15 U. Ledóchowska, Rozmyślania dla Sióstr Urszulanek Serca Jezusa Konającego, dz. cyt., s. 72.

${ }_{16}$ Zob. U. Ledóchowska, Rozmyślania dla Sióstr Urszulanek Serca Jezusa Konającego, dz. cyt., s. 73.

Zob. U. Ledóchowska, Rozmyślania dla Sióstr Urszulanek Serca Jezusa Konającego, dz. cyt., s. 74 .

18 U. Ledóchowska, Rozmyślania dla Sióstr Urszulanek Serca Jezusa Konającego, dz. cyt., S. $88-89$. 
w ręce Chrystusa, z całkowitą ufnością i powierzeniem się Temu, który jest pełen dobroci i miłosierdzia:

O Jezu, i ja chcę być Twą ofiarą. Patrz, oddałam się Tobie na ofiarę całopalną przez śluby święte, więc należę do Ciebie. Możesz uczynić ze mną wszystko, co Ci się podoba, jam ofiarą Twoją, więc na wszystko się zgadzam. Rób ze mną, co chcesz, jak chcesz, kiedy chcesz, bylebym była ofiarą, bylebym trawiła się na ołtarzu Twej miłości, dopóki się zupełnie nie strawię ${ }^{19}$.

Tymi słowami założycielka Zgromadzenia Sióstr Urszulanek Serca Jezusa Konającego wyznacza drogę, którą podąża każda siostra pragnąca żyć charyzmatem swej rodziny zakonnej. Święta wyjaśnia zarazem, co w praktyce oznacza bycie ofiarą. Zostawia następujące wskazania, które w tym miejscu warto przytoczyć:
Jam ofiarą, więc palić się mam w modlitwie, aż się spalę, choć nieraz modlitwa z trudem mi przychodzi. Trawić się w pokucie, aż się strawię, choć żal prawdziwy, który jest najlepszą pokutą, niełatwo mi przychodzi i domaga się wysiłku natury. Mam ogarnąć miłością swoje otoczenie, swych bliźnich, cały świat, aż w tej miłości, w tym poświęceniu wyniszczę swoje ,ja” i tak na wzór Serca Jezusowego stanę się prawdziwą, całopalną ofiarą, ofiarą za moje grzechy ${ }^{20}$.

Umiłowanie Serca Jezusa Konającego prowadzi do życia wypełnionego modlitwą, umartwieniem i ofiarną miłością bliźniego. Według św. Urszuli prawdziwy czciciel Jezusa Ukrzyżowanego chce wielkodusznie odpowiadać na miłość Jego Serca.

\section{Wsłuchiwanie się w Jezusowe wyznanie „Pragnę"}

Kontemplacja Serca Jezusa Konającego skłania do odczytywania słów Zbawiciela, wypowiedzianych przez Niego z wysokości krzyża. Matka Ledóchowska zatrzymuje się szczególnie przy Jezusowym wyznaniu: „Pragnę". Odczytuje i wyjaśnia krzyk Chrystusa jako wyraz nie tylko cierpienia fizycznego, ale także bólu moralnego i duchowego, wypływającego z widoku tak wielu ludzi, którzy odwracają się od Niego. Święta Urszula kieruje do Pana słowa modlitwy:

19 U. Ledóchowska, Rozmyślania dla Sióstr Urszulanek Serca Jezusa Konającego, dz. cyt., s. 89.

20 U. Ledóchowska, Rozmyślania dla Sióstr Urszulanek Serca Jezusa Konającego, dz. cyt., s. 89. 
Jezu, klęcząc u stóp Twego krzyża, uprzytomnię sobie, kim jesteś, Ofiaro moja, krwią oblana, konająca w niewypowiedzianych mękach. Tyś Bóg mój i Pan, wielki, trzykroć święty, Ten, który był, jest i będzie. A tu, na tym krzyżu, „robak, a nie człowiek, pośmiewisko ludu i wzgarda pospólstwa" (Ps 22,7) [...]. Kochasz nas. Nie jesteśmy Ci potrzebni do Twego szczęścia, ale my Ciebie potrzebujemy, a Ty się dla nas ofiarowujesz z miłości. O, żebym umiała pojąć cały ogrom Twej miłości i zrozumieć, ile jej się zawiera w Twoim wołaniu „Pragnę"

Według św. Urszuli, odkrycie niepojętej miłości Boga do człowieka jest doświadczeniem kierunkującym całe życie wierzącego. Dlatego zachęca ona, by odważyć się zająć miejsce umiłowanego ucznia i stanąć pod krzyżem. Wtedy dopiero dostrzega się miłość Boga, objawiającą się najpełniej na krzyżu, w Sercu Jezusa Konającego. Matka Urszula pokazuje, że osobiste wsłuchiwanie się w słowo „Pragnę”, pociąga za sobą prośbę o łaskę, by serce człowieka umiało doznać poruszenia pod wpływem tego wołania wypełnionego miłością i wyrażającego ogrom bólu² ${ }^{22}$.

Wezwanie Jezusa „Pragnę”, Matka Ledóchowska słyszy i odczytuje bardzo osobiście, swoim sercem, jako wołanie o miłość, jako pragnienie miłości, na którą chce odpowiedzieć darem z samej siebie dla Boga. Do takiej postawy zachęca zarazem swoje duchowe córki. Pisze w Testamencie, zwracając się do sióstr, że urszulanka Serca Jezusa Konającego ma za zadanie wsłuchiwać się w bolesną skargę wydobywającą się z ust konającego na krzyżu Pana: „Pragnę” (J 19, 28)23. Matka zaznacza, że ten okrzyk Jezusa to jęk Serca przepełnionego bólem spowodowanym tym, że ludzie odrzucają Miłość, że nie chcą korzystać z łask, którymi Jezus mocą Jego męki i śmierci - pragnie obdarzać każdego. „Pragnie Jezus, a to pragnienie takie straszne, że On, który nigdy na nic się nie skarżył, od tej skargi jakby powstrzymać się nie może"24 - zauważa św. Urszula. Wyjaśnia, że Chrystus pragnie tych, którzy chcieliby odpowiedzieć na Jego miłość; tych, których On mógłby obdarzać łaskami i prowadzić ich do wiecznej szczęśliwości, do nieba, gdzie miejsce już jest

${ }^{21}$ U. Ledóchowska, Rozmyślania dla Sióstr Urszulanek Serca Jezusa Konającego, t. 1, Pniewy 2000, s. 264-265.

${ }^{22}$ Zob. U. Ledóchowska, Rozmyślania dla Sióstr Urszulanek Serca Jezusa Konającego, dz. cyt., s. 264.

${ }_{23}$ Zob. U. Ledóchowska, Pisma zakonne, dz. cyt., s. 63.

24 U. Ledóchowska, Pisma zakonne, dz. cyt., s. 63. 
przygotowane ${ }^{25}$. Autorka Rozmyślań wnika więc w najgłębsze pragnienia Chrystusa - potrafi nie tylko je dostrzec i zrozumieć, ale także chce na nie odpowiadać. Zauważa:

\begin{abstract}
Nie ma miłości ten, kto nie czuje pragnienia przyniesienia ulgi cierpiącemu przyjacielowi, a czy Jezus nie jest naszym najlepszym Przyjacielem? Czy nie powinnam więc być gotowa na wszelką ofiarę, byleby choć trochę pocieszyć Jego Serce, tak srodze zranione? ${ }^{26}$
\end{abstract}

Dlatego, według Matki Ledóchowskiej, obowiązkiem ludzi kochających Jezusa jest zadośćuczynienie Mu za wyrządzane zniewagi, za ból zadany Jego Sercu.

Święta Urszula, wpatrując się w wyniszczone z miłości i zranione ludzkimi grzechami Serce Jezusa Konającego, pisze: „Chcę pamiętać o tym, coś dla mnie uczynił, o dobry Jezu, i chcę, chcę z miłości ku Tobie zetrzeć w proch moje własne «ja». Niech ono nie żyje, byś Ty, o Jezu, mógł żyć we mnie"27. Miłość do Chrystusa przynagla do dystansowania się do swoich własnych nieuporządkowanych upodobań, próżności, chęci zwracania uwagi na siebie, ambicji, lenistwa. Według Matki Ledóchowskiej to właśnie jest owoc łaski Boga płynącej z prawdziwej kontemplacji Serca Jezusa. Zaleca ona nieustannie ćwiczyć się w drobnych umartwieniach. Poleca, by myśl o Sercu Zbawiciela, pełnym bólu z powodu grzechów, zachęcała do czynów miłości. „Jezus tyle za mnie cierpiał, a ja dla Niego nic nie chcę uczynić? On pokutuje za moje grzechy, a ja czyż nie chciałabym za nie pokutować?"28 - pyta autorka Rozmyślań. Zauważa, że autentyczne odkrywanie ofiarnej miłości Chrystusa prowadzi do działania motywowanego miłością.

Kontemplacja Jezusa Ukrzyżowanego i Jego przebitego Serca oraz wsłuchiwanie się w wołanie „Pragnę” pozwala odkrywać to, czego Bóg oczekuje od człowieka wierzącego, a dla św. Urszuli jest to kwestia fundamentalna. W Dyrektorium przypomina ona swoim duchowym córkom,

\footnotetext{
25 Zob. U. Ledóchowska, Pisma zakonne, dz. cyt., s. 63.

26 U. Ledóchowska, Rozmyślania, t. 1, dz. cyt., s. 267.

27 U. Ledóchowska, Rozmyślania, t. 2, dz. cyt., s. 78.

28 U. Ledóchowska, Rozmyślania, t. 2, dz. cyt., s. 78.
} 
jak ważne jest, aby wiedziały, czego Pan Bóg wobec nich chce. Zwraca uwagę, że siostry urszulanki - nazwane przez Świętą służebnicami Serca Jezusa Konającego - mają kierować wzrok na krzyż, aby mogły zrozumieć pragnienie Serca Zbawiciela. Matka Ledóchowska zachęca:

Wpatrujmy się w to Serce! Otoczone jest płomieniami miłości, które nam przypominają: Kochajcie, jak Ja was kochałem! Ciernie Je okalają i zdają się na nas wołać: Czyńcie pokutę, tak jak Ja pokutowałem! ${ }^{29}$

Tymi słowami św. Urszula podkreśla, że duch miłości i pokuty jest szczególnie zadany osobom poświęconym Bogu ${ }^{30}$. Odczytywanie tego, do czego Bóg zaprasza człowieka następuje więc poprzez osobiste zwrócenie się do Zbawiciela. Skierowując wzrok na krzyż, można zrozumieć pragnienia Konającego Serca Pana.

Wsłuchiwanie się w bolesne wezwanie „Pragnę” pozwala rozpoznać w Sercu Jezusowym miłość odrzuconą i wzgardzoną. Matka Urszula odczytuje to słowo Zbawiciela w świetle zdania z Księgi Psalmów: „Jaki będzie pożytek z krwi mojej, z mojego zejścia do grobu?" (Ps 30, 10). Wyobraża sobie podczas medytacji, że słowa te wciąż rozbrzmiewają w wypełnionej bólem duszy Zbawiciela, który wyznaje: „Cóż za pożytek z krwi mojej, z bólu mego, z męki mojej i śmierci mojej, skoro ludzie nie chcą korzystać z łask im wysłużonych i odrzucają rękę, którą do nich wyciągam, by ich ratować!”31. W świetle tej skargi Jezusa Matka Ledóchowska odczytuje Jego wyznanie: Sitio - „Pragnę”. Autorka Rozmyślań odkrywa, że Zbawiciel pragnie, by ogień Jego miłości zapłonął i rozpalał się coraz bardziej w sercach wszystkich ludzi. Święta Urszula zachęca siostry, by modliły się słowami:

O Jezu mój, konający na krzyżu, szczególnie przez te dni, gdy świat o Tobie zapomina, chcę dołożyć wszelkich starań, by stać się pociechą dla Serca Twego i choć małymi, ale jak najliczniejszymi ofiarami oraz miłością odpowiadać na Twój jęk boleści: Pragnę ${ }^{32}$.

29 U. Ledóchowska, Pisma zakonne, dz. cyt., s. 80-81.

30 Zob. U. Ledóchowska, Pisma zakonne, dz. cyt., s. 80-81.

31 U. Ledóchowska, Rozmyślania, t. 1, dz. cyt., s. 266.

32 U. Ledóchowska, Rozmyślania, t. 1, dz. cyt., s. 267. 
Ponadto udziela ona swym duchowym córkom wskazań, w jaki sposób całym życiem odpowiadać na wezwanie Jezusa: „Pragnę” tak, aby być „pociechą dla Serca Jezusowego”33. Matka Ledóchowska nie ma tu na myśli płytkiego wymiaru uczuciowego, lecz wskazuje na zdolność życia miłością, modlitwą i pokutą. Zaleca rozpoczynać dzień od ofiarowania go Sercu Jezusowemu. Podczas codziennej adoracji zachęca do wpatrywania się w Pana i kierowania do Niego prośby, by On nauczył - choć w niewielkim stopniu - rozumieć ogrom Jego miłości ku ludziom i „płacić Sercu Jezusowemu miłością za miłość, ofiarą za ofiarę, choćby krwią za krew"34.

Wezwanie Zbawiciela „Pragnę” nie jest w stanie wyrazić całego ogromu miłości, którą Chrystus obdarza każdego człowieka. Matka Ledóchowska wskazuje, że miłość Jezusa objawia się nie tylko w słowach, ale także przez gest przebicia Serca Jezusa włócznią, który pozwala niejako wypłynać pragnieniom Chrystusa. Zranione Serce jest przebłaganiem za grzechy ludzi. Święta Urszula, wpatrując się w skrwawione i otwarte Serce Pana rozważa, dla kogo ono jest tak zranione. Rana miłości wskazuje na otwarcie dla wszystkich. Święta Urszula zauważa w swoich rozważaniach przeznaczonych dla sióstr:

Serce, przebite włócznią - dla nas szeroko otwarte, jak gdyby chciało nas zaprosić, byśmy przybyli i czerpali z pełności Jego łask. Boskie Serce pragnie dać mi ich jak najwięcej. Cieszy się, gdy przychodzę, by z tej pełności czerpać siły dla biednej duszy mojej $j^{35}$.

Serce Jezusa Konającego chce być bezpiecznym miejscem schronienia dla każdego człowieka, dla serc szukających Boga i zbawienia.

3 U. Ledóchowska, Pisma zakonne, dz. cyt., s. 108.

34 U. Ledóchowska, Pisma zakonne, dz. cyt., s. 108; zob. M. Pagacz, Odpowiadanie na Jezusowe „Pragnę" (J 19, 28) jako istotny rys duchowości i misji św. Urszuli Ledóchowskiej i św. Matki Teresy z Kalkuty, „Bielańskie Studia Teologiczne” 2 (2016), s. 65-77.

35 U. Ledóchowska, Rozmyślania, t. 2, dz. cyt., s. 67. 


\section{Apostolstwo odpowiedzią na miłość i pragnienia Chrystusa}

Osoba kontemplująca nieskończoną miłość Chrystusa, wpatrująca się w Jego przebite Serce, zranione grzechami i cierpiące, wezwana jest do odpowiedzi Bogu - do odpowiedzi pełnej wielkodusznej miłości. Ten, kto modli się, patrząc w Konające Serce Zbawiciela, słyszy także krzyk Jezusa, płynący z krzyża: „Pragnę”. Pytanie, wobec którego staje człowiek kontemplujący Chrystusa ukrzyżowanego, brzmi więc: jak mogę odpowiedzieć na pragnienie Pana Jezusa? Święta Urszula pokazuje, że prawdziwa modlitwa prowadzi do otwarcia się na łaskę Zbawiciela i do odnalezienia własnej, osobistej odpowiedzi na to pytanie, czerpiąc światło od Ducha Świętego. Z tego właśnie doświadczenia - zdaniem św. Urszuli - wypływa postawa apostolska.

W Rozmyślaniach Matka Ledóchowska zapisuje słowa, które jednoznacznie pokazują, jak rozumie ona ducha apostolstwa: „Oto jedna z prawdziwych oznak naszej miłości ku Chrystusowi: duch apostolstwa - pragnienie, by wszyscy coraz goręcej Jezusa kochali, coraz lepiej Go znali"”36. Dokładanie starań, by inni ludzie odkrywali dobroć Chrystusa i miłowali Go jest - według św. Urszuli - wiarygodnym świadectwem miłości do Zbawiciela. Autorka Rozmyślań zaleca więc siostrom, by na modlitwie stawiały sobie następujące pytania:

Czy moja miłość ku Jezusowi objawia się w duchu apostolskim? Czy o to mi chodzi, by dusze mi powierzone, dusze tych, z którymi mam do czynienia, coraz goręcej Boga kochały, coraz lepiej Go poznawały i coraz gorliwiej nad sobą pracowały? Czy modlę się za te dusze? Czy proszę Boga o ich postęp w cnocie i staram się być dla nich dobrym przykładem? ${ }^{37}$

Święta Urszula pokazuje, że człowiek prawdziwie miłujący Boga jest przeniknięty pragnieniem, by Bóg był miłowany, uwielbiony i wysławiany przez wszystkich.

Matka Ledóchowska w Rozmyślaniach przypomina swym duchowym córkom, jaka jest ich prawdziwa tożsamość i powołanie. Pisze:

36 U. Ledóchowska,, Rozmyślania, t. 1, dz. cyt., s. 164.

37 U. Ledóchowska, Rozmyślania, t. 1, dz. cyt., s. 165. 
Jam własnością Boskiego Serca Jezusowego i nie należę do siebie, bo Chrystus kupił mnie sobie za wielką cenę (zob. 1 Kor 6, 20; 7, 23). Nie wolno mi inaczej myśleć jestem własnością Serca Jezusowego ${ }^{38}$.

Zauważa, że właśnie ta świadomość jest źródłem prawdziwego szczęścia, bo kto należy do Chrystusa jest w pełni przyjęty i umiłowany. Relacja należenia do Zbawiciela pociąga za sobą - według św. Urszuli - dalsze reperkusje: wskazuje, że człowiek nie jest stworzony dla siebie, nie jest przeznaczony do spełniania swoich egoistycznych upodobań, lecz ma pełnić wolę Pana Boga. Autorka Rozmyślań postanawia: „Nie będę szukała własnego zadowolenia ani swojej woli, ale zadowolenia Jezusa i Jego świętej woli"39. I prosi Boskie Serce, by Ono ją wspierało, aby w całym życiu należała wyłącznie do Chrystusa i żyła jedynie dla Niego ${ }^{40}$. Święta Urszula również poleca siostrom ogarniać miłością bliźnich i cały świat, a zwłaszcza tych najbardziej potrzebujących i słabych. Zachęca, by być pełnym poświęcenia, nie patrząc na swoje „ja”, i na wzór Serca Jezusowego stać się prawdziwą, całopalną ofiarą ${ }^{41}$.

Matka Ledóchowska wskazuje, że ten, kto trwa przy Sercu Jezusa Konającego, od kontemplacji przechodzi do czynów miłości bliźniego. Dlatego przynagla siostry:

Niech w sercach Waszych tli się nieustannie święty ogień miłości dusz. Zbawić dusze, prowadzić dusze do Jezusa, dać im poznać nieskończoną dobroć Serca Jezusowego - oto ideał, dla którego poświęcić się mamy ${ }^{42}$.

Słowa te wyrażają istotę apostolstwa w rozumieniu św. Urszuli. Autentyczne apostolstwo wypływa z pragnienia, by Chrystus był znany i miłowany przez wszystkich. Chrystus pragnie bowiem dusz, które by Go miłowały, na które mógłby wylewać łaski. Dlatego - według założycielki Zgromadzenia Sióstr Urszulanek Serca Jezusa Konającego - ukierunkowanie serc ludzkich ku Sercu Bożemu i pomoc w odkrywaniu Jego ogromnej miłości jest podstawowym zadaniem apostolskim. Podejmowanie

\footnotetext{
U. Ledóchowska, Rozmyślania, t. 2, dz. cyt., s. 56-57.

U. Ledóchowska, Rozmyślania, t. 2, dz. cyt., s. 56-57.

Zob. U. Ledóchowska, Rozmyślania, t. 2, dz. cyt., s. 56-57.

Zob. U. Ledóchowska, Rozmyślania, t. 2, dz. cyt., s. 89.

U. Ledóchowska, Pisma zakonne, dz. cyt., s. 63.
} 
wysiłku i dokładanie starań, by najczystsza i samoudzielająca się miłość Zbawiciela mogła zostać przyjęta, by nie spotkała się z odrzuceniem, stoi u podstaw wszelkich działań, inicjatyw i czynów miłosierdzia.

Święta Urszula wielokrotnie bardzo konkretnie pokazuje, czym jest apostolstwo, do którego zobowiązane są zwłaszcza osoby poświęcone Bogu na własność. Stwierdza:

Kto kocha Boga, pragnie i innych do miłości Bożej zachęcić. Jeżeli kto, to przede wszystkim dusza zakonna powinna starać się o to, by siłą miłości dusze do Jezusa pociągać i stać się apostołką nie tyle słowem, co przykładem, dobrocią, serdecznością, modlitwą, a może przede wszystkim pogodą ducha ${ }^{43}$.

Autorka Rozmyślań ukazuje różnorodne formy i sposoby apostołowania, a u podstaw każdego zaangażowania i posłannictwa jest pragnienie, by innych prowadzić do umiłowanego nade wszystko Boga. Dlatego założycielka Zgromadzenia Sióstr Urszulanek Serca Jezusa Konającego przypomina swym duchowym córkom, że całe ich życie jest - poprzez czynną miłość i pokutę - wyrazem wynagrodzenia Sercu Zbawiciela za grzechy własne i innych ludzi.

„Serce Konające Jezusa, jakże Ciebie nie kochać za wszystko, coś dla nas uczyniło!"44 - zwraca się do Zbawiciela autorka Rozmyślań. Ta modlitwa jest wyrazem autentycznego ducha apostolskiego, który przejawia się w konkretnych postawach, w słowach i czynach podejmowanych po to, by inni mogli poznać Chrystusa i doświadczyć Jego miłości. Święta Urszula podaje zarazem wiele sposobów apostolstwa - należą do nich: modlitwa, cierpienie i pokuta, świadectwo życia oddanego Bogu, wszelkie czyny miłości i służby wobec innych, praca i apostolstwo uśmiechu. W Rozmyślaniach pisze:

Mam być apostołką, i mogę nią być - przez pracę, przez miłość bliźniego, przez dobroć, przez pogodę ducha. To jest to prawdziwe apostolstwo, które czasem więcej działa aniżeli słowa. Niech więc i w moim sercu goreje ten święty ogień gorliwości o zbawienie dusz $z^{45}$.

\footnotetext{
43 U. Ledóchowska, Rozmyślania, t. 1, dz. cyt., s. 87.

${ }_{44}$ U. Ledóchowska, Rozmyślania, t. 1, dz. cyt., s. 87.

45 U. Ledóchowska, Rozmyślania, t. 2, dz. cyt., s. 365.
} 
Człowiek, który miłuje Boga i chce innych do Niego prowadzić, wykorzystuje ku temu wszystkie sytuacje życiowe, wypowiadane słowa, podejmowane działania i wszelkie doświadczenia, w których uczestniczy.

Idąc za wskazaniami pozostawionymi przez Matkę Ledóchowską, siostry zjednoczone w apostolskiej wspólnocie Zgromadzenia Sióstr Urszulanek Serca Jezusa Konającego kierują swe wysiłki ku temu, by życiem i działalnością nieść innym Dobrą Nowinę, uczestnicząc z Kościołem i w Kościele w wypełnianiu Bożego planu zbawienia. Szczególną misją Zgromadzenia jest głoszenie Chrystusa - miłości Jego Serca - przez wychowanie i nauczanie dzieci i młodzieży, służbę braciom najbardziej potrzebującym i pokrzywdzonym oraz przez inne formy działania mające na celu ewangelizację świata ${ }^{46}$.

\section{Zakończenie}

Reasumując, tajemnica Serca Jezusa Konającego znajduje się u podstaw duchowości i misji św. Urszuli Ledóchowskiej i zgromadzenia przez nią założonego. Serce Zbawiciela, oddającego życie dla zbawienia wszystkich ludzi, wyraża największą i najczystszą miłość, jaka podarowana może być człowiekowi. Słowem Chrystusa bezpośrednio związanym z rozważaną tajemnicą jest - przenikający głębię duszy ludzkiej - krzyk Ukrzyżowanego Zbawiciela: „Pragnę”. Ma on kluczowe znaczenie w pismach i duchowości św. Urszuli. Rozlega się z ust konającego Pana, z wysokości krzyża. Nie wyraża jednak tylko pragnienia naturalnego - wołanie „Pragnę” niesie ze sobą tajemnicę. Jest to jęk Serca przepełnionego bólem i miłością - to wyraz cierpienia Zbawiciela wynikającego ze świadomości, że jedynie nieliczne dusze chcą przyjąć łaski, które płyną z Jego męki i śmierci.

Święta Urszula nie pozostaje obojętna wobec Jezusowej prośby. Wzywa również swoje duchowe córki, by dawały wyraz swej osobistej więzi z Chrystusem, z Jego Konającym Sercem, przez podejmowanie wysiłku, by w modlitwie, czynach miłości i pokuty zaspokajać pragnienia i 75 .

${ }^{46}$ Zob. Konstytucje Zgromadzenia Sióstr Urszulanek Serca Jezusa Konającego, dz. cyt., s. 14 
Zbawiciela. Chce doprowadzić siostry do nieustannego ofiarowywania swego życia Chrystusowi i zachęca je, aby dokładały starań, by wszystkich kierować do Niego. Dla Matki Ledóchowskiej odpowiedzią na miłość Bożego Serca, na usłyszaną skargę Jezusa, jest konkretna postawa apostolska. Zdaniem założycielki Zgromadzenia Sióstr Urszulanek Serca Jezusa Konającego apostolstwo rodzi się przede wszystkim z głębokiego pragnienia, by wszyscy ludzie poznali i umiłowali Zbawiciela, a polega ono na podejmowaniu różnorakich wysiłków, by tak mogło się stać.

Apostolstwo jest ukazane jako owoc kontemplacji tajemnicy Serca Jezusa Konającego, co wyjaśnia, jak św. Urszula rozumie pełnienie posłannictwa w Kościele. Według Matki Ledóchowskiej wszelkie słowa wypowiadane przez ludzi i podejmowane działania mają sens o tyle tylko, o ile są odpowiedzią na niezmierzoną i niepojętą miłość Serca Zbawiciela. Prawdziwe apostolstwo jest wysiłkiem zmierzającym ku temu, by Pan Jezus był znany i miłowany przez wszystkich. Aktywności, które nie są motywowane pragnieniem prowadzenia innych do Chrystusa, są jedynie pozorami dobra. Oprócz tego przedstawienie tajemnicy Serca Jezusa Konającego jako źródła apostolstwa według Matki Urszuli daje uzasadnienie jedności modlitwy i działania, kontemplacji i aktywności, którą Święta wielokrotnie podkreśla i przypomina w swoich pismach. Według niej pełnienie zadań i służba w Kościele jest owocem medytacji i kontemplacji, a prawdziwa modlitwa nie pozwala zamknąć się w bierności ani trwać w iluzji pobożności.

Z przeprowadzonych analiz wyłaniają się także wskazówki odnoszące się do duchowości i misji Zgromadzenia Sióstr Urszulanek Serca Jezusa Konającego we współczesności, w obecnych uwarunkowaniach Kościoła oraz świata. Rozważania św. Urszuli, będące wezwaniem do kontemplacji Serca Zbawiciela i do wsłuchiwania się w Chrystusowe „Pragnę”, są nie tylko w pełni aktualne w dzisiejszych czasach i realiach, lecz ponadto obecnie nabierają szczególnego znaczenia. Tym bardziej, że we współczesnym świecie dominuje pośpiech i wiele bodźców powodujących rozproszenie, stąd zachowanie harmonii łączącej modlitwę i działanie niejednokrotnie sprawia trudność osobom konsekrowanym. Refleksje Matki Ledóchowskiej dotyczące tajemnicy Serca Jezusa Konającego stanowią istotną podpowiedź, w jaki sposób rzetelnie rozeznawać wolę Pana 
Boga, odpowiadając na Jego niepojętą miłość. Co więcej, warto podkreślić, że przedstawione zalecenia św. Urszuli stają się nieodzowne w obliczu konieczności rozeznawania podejmowanych zaangażowań, w kontekście zmniejszającej się liczebności osób należących do Zgromadzenia i - co za tym idzie - wobec nieuchronności ograniczenia wielości dzieł apostolskich.

\section{Bibliografia}

Konstytucje Zgromadzenia Sióstr Urszulanek Serca Jezusa Konajacego, Warszawa 2016.

Ledóchowska U., Rozmyślania dla Sióstr Urszulanek Serca Jezusa Konającego, t. 1, Pniewy 2000.

Ledóchowska U., Rozmyślania dla Sióstr Urszulanek Serca Jezusa Konającego, t. 2, Pniewy 2000.

Ledóchowska U., Pisma zakonne, Pniewy 2000.

Misiurek J., Kontemplacja Serca Jezusa Konającego i duchowość eucharystyczna, w: Polka w Europie. Święta Urszula Ledóchowska, red. M. Chmielewski, Z. Zdybicka, M. Ziółkowska, Lublin 2005, s. 28-42.

Misztal W., „Testament” św. Urszuli jako synteza duchowości. Lektura tylko dla urszulanek Serca Jezusa Konającego?, w: Św. Urszula Ledóchowska: kobieta w Kościele i społeczeństwie, red. M. Krupecka, W. Misztal, Kraków 2015, s. 71-93.

„Otrzymała od Ducha Świętego wielki charyzmat”. Św. Urszula Ledóchowska i Urszulanki Serca Jezusa Konającego, red. M. Krupecka, W. Misztal, Kraków 2012.

Pagacz M., Odpowiadanie na Jezusowe „Pragnę” (J 19,28) jako istotny rys duchowości i misji św. Urszuli Ledóchowskiej i św. Matki Teresy z Kalkuty, „Bielańskie Studia Teologiczne" 2 (2016), s. 65-77.

Polka w Europie. Święta Urszula Ledóchowska, red. M. Chmielewski, Z. Zdybicka, M. Ziółkowska, Lublin 2005.

Św. Urszula Ledóchowska: kobieta w Kościele i społeczeństwie, red. M. Krupecka, W. Misztal, Kraków 2015.

Zyzak W., Kontemplacja Krzyża jako centrum duchowości św. Urszuli Ledóchowskiej, w: „Otrzymała od Ducha Świętego wielki charyzmat”. Św. Urszula Ledóchowska i Urszulanki Serca Jezusa Konającego, red. M. Krupecka, W. Misztal, Kraków 2012, s. 73-94. 